\title{
Deaths from primary brain cancers, lymphatic and haematopoietic cancers in agricultural workers in the Republic of Ireland
}

\author{
Geoffrey Dean
}

\begin{abstract}
Study objective - To ascertain if agricultural workers in the Republic of Ireland had a higher than expected mortality from brain and haematopoietic cancers than occurred in the general population. Design - The Central Statistics Office of Ireland provided computer analysis of all deaths coded as cancer of the brain, ICD 191, and of lymphatic and haematopietic cancers, ICD codes 200-208, by socioeconomic, sex, and age groups, from 1971 to 1987. The deaths were then analysed by socioeconomic group and compared with the expected number of deaths in the general population.
\end{abstract}

Setting - A cluster of four deaths from primary brain cancer, three from leukaemia, and one from Hodgkin's disease, occurred in the research and technical staff of the former Agricultural Institute of the Republic of Ireland in men under the age of 65 . This raised the question, were farmers more likely to get these forms of cancer due toexposure to herbicides or fertilisers?

Subjects - All deaths in the Republic of Ireland from 1971 to 1987 by socioeconomic group.

Main results - Although deaths reported as due to primary brain cancers had increased in all socioeconomic groups in the two time periods studied, there was no greater increase in farmers and a smaller increase in other agricultural workers and fishermen. Deaths from Hodgkin's disease and multiple myeloma, and to a smaller extent from leukaemia, had also increased. The increase in reported mortality of these haematopoietic cancers in farmers was no greater and in other agricultural workers it was less than in the general population.

Conclusion - There was no evidence that farmers had any greater increase in mortality from these cancers than the general population. The cluster of brain and haematopoietic cancers in research and technical staff at the Agricultural Institute of the Republic of Ireland does not reflect a high risk of these cancers among the general farming population, but strongly supports the need for a compilation of a register of causes of death of laboratory workers in a number of countries.

( $\mathcal{F}$ Epidemiol Community Health 1994;48:364-368)
An investigation in 1985 into the causes of death in male research and technical staff employed by the Agricultural Institute of Ireland, showed that there were four deaths from primary brain cancer, three from leukaemia, and one from Hodgkin's disease among the 11 deaths from cancer out of 28 total deaths. Another member of the Institute's technical staff was suffering from a lymphatic cancer. The cluster of deaths from brain and haematopoietic cancers among the research and technical staff, who had worked in different branches of the Institute, could have been due to radiation from radioactive isotopes, a viral infection, or a chemical hazard from some substance used in agriculture or research, or it could have been a very unusual chance occurrence.

About the same time it was reported that a cluster of rare cancers (sarcoma, lymphoma) was occurring among laboratory workers at the Pasteur Institute in Paris; a follow up study showed an excess of bone, pancreas and brain cancer deaths but the numbers were small $(2,5$ and 3$)^{2}$ The Orsay Institute in Paris also reported a greater than expected number of brain tumours. ${ }^{3}$ Rutty et al reported a cluster of brain cancers - gliomas - in three pathology laboratory technicians ${ }^{4}$ and Hall et al reported increased mortality from gliomas among pathologists and other medical laboratory personnel. ${ }^{5}$ Pierce et al reported an increased mortality from leukaemia in agriculture and forestry workers in New Zealand ${ }^{6}$ and Belli et al found an increased risk for a number of cancers in a mortality study of research workers employed by the Italian National Institute of Health, pointing to an excess risk for some cancers. Laboratory workers in England aged 18-64 had a small but significantly increased mortality from brain cancer. ${ }^{8}$

Because the research workers in the Agriculture Institute in Ireland might have been unduly exposed to some agricultural chemical, such as a fertiliser or pesticide, which might increase the risk of developing brain or haematopoietic cancer and which might be affecting farmers in general in Ireland, a study was undertaken on deaths from these groups of cancers among farmers, relatives assisting farmers, and among farm managers (socioeconomic group 0 (SEG 0)) and also among other agricultural occupations and fishermen (SEG 1 ), in comparison with the other socioeconomic groups and with the general population.

Method

The Central Statistics Office (CSO) of Ireland
Research Board of Ireland G Dean 
provided computer analysis of all deaths coded as cancer of brain (ICD 191) and of the lymphatic and haematopoietic cancers (ICD codes 200-208) by socioeconomic, sex, and age group from 1971 (the first year when this information was available) to 1987. These data were not available for specific occupations but only by socioeconomic group. The lymphatic and haematopoietic cancers were subdivided into lymphoid cancers and Hodgkin's disease (ICD 200-202), multiple myeloma (ICD 203), lymphoid leukaemia (ICD 204), myeloid leukaemia (ICD 205), and monocytic and other leukaemias (ICD 206-208). In this last group, death was usually described as from "leukaemia", with the type not specified.

The populations at risk by SEG, sex, and age group were obtained from the 1971 and 1981 censuses. The SEG is based on the gainful occupation, past or present, stated at the census, where there is a specific question, and on the death certificate. More people are described on their death certificate as "occupation unknown", "housewife", or "retired" than at the census. Farmers and their relatives (SEG 0) seldom retire from their farms, so there are relatively few farmers in the unknown SEG group (SEG Y). Those in the group, "other agricultural occupations and fishermen" (SEG 1) are mostly farm labourers.

The SEGs were only available from the Central Statistics Office from 1971 onwards. Two time periods were, therefore, studied - 1971-78 and 1979-87. Comparison was then made with the rates by sex and age group for all deaths in the Republic of Ireland during the two 10 year periods 1968-77 and 1978-87.

\section{Results}

The greatest increase in reported cancer deaths in the population of the Republic of Ireland has been for brain cancer. During the 20 years 1968-87, 1280 male and 872 female deaths were reported as due to primary brain cancer, and the number of brain cancer deaths doubled between 1968-77, (721 deaths) and 1978-87 (1431 deaths). More leukaemia deaths were classified during the second time period studied as myeloid or lymphatic leukaemia and fewer as leukaemia (type not stated). If all forms of leukaemia are combined, there is only a small increase in leukaemia deaths - from 1570 in
$1968-77$ to 1819 in 1978-87. Deaths from lymphoid cancer and Hodgkin's disease increased from 1109 to 1548 (1606 males, 1051 females), and those from multiple myeloma from 637 to 1001, (894 males, 744 females).

The death rates per $100000 /$ year from brain cancers have been compared for farmers, relatives assisting farmers, and farm managers (SEG 0) for two time periods, 1971-78 and 1979-87, in comparison with that of the total population by sex and age group in table 1 . The farmers do not have any significant difference in brain cancer mortality in the different age groups to that in the population as a whole. The greatest increase in brain cancer deaths, both in farmers and in the general population, occurred over the age of 65 years.

For the last nine years of the study (1979-87) the actual and expected number of deaths from cancer of the brain have been calculated for all SEGs (table 2). There is an excess of deaths among those in the "unknown group" (SEG Y), compared with the expected number based on the populations at risk. For comparison purposes this excess has been divided proportionately among all the other socioeconomic groups in the last column of the table. Farmers (SEG 0) do not have significantly more brain cancer deaths than expected -240 deaths and 264.3 expected. If the excess proportion of deaths in the unknown SEG are added, then there would be 268 deaths among the farmers, compared with 264 expected.

Deaths from brain cancer among "other agricultural occupations and fishermen" (SEG 1) are significantly fewer than expected $\left(\chi^{2}=23 \cdot 7\right.$ $\mathrm{p}<0.001)$. When SEGs 0 and 1 are taken together there were 267 male and female brain cancer deaths, and 316.6 is the calculated expected number $\left(\chi^{2}=7.7 \mathrm{p}<0.01\right)$. Most of the men in SEG 1 are agricultural labourers and it seems probable that they are frequently described as "farmers" (SEG 0) on the death certificate, but as farm labourers (SEG 1) at the census.

The actual and expected number of deaths for all the cancers studied in farmers and in farmers and other agricultural occupations and fishermen combined are shown by sex and in two age groups in table 3 . Both in the 15-64 age group and in the $65+$ age group in farmers (SEG O), there is no significant difference between the actual and number of deaths and

Table 1 Republic of Ireland deaths from malignant neoplasm of the brain (ICD 191) in farmers, relatives assisting farmers and farm managers compared with all deaths (rates/100000/y)

\begin{tabular}{|c|c|c|c|c|c|c|c|c|}
\hline \multirow[b]{2}{*}{$\begin{array}{l}\text { Age } \\
\text { group (y) }\end{array}$} & \multicolumn{4}{|l|}{ Men } & \multicolumn{4}{|l|}{ Women } \\
\hline & $\begin{array}{l}\text { Farmers } \\
(S E G \quad 0) \\
8 y \\
1971-78\end{array}$ & $\begin{array}{l}\text { All } \\
\text { SEGs } \\
10 y \\
1968-77\end{array}$ & $\begin{array}{l}\text { Farmers } \\
(S E G \quad 0) \\
9 y \\
1979-87\end{array}$ & $\begin{array}{l}\text { All } \\
\text { SEGs } \\
10 y \\
1978-87\end{array}$ & $\begin{array}{l}\text { Farmers } \\
(S E G 0) \\
8 y \\
1971-78\end{array}$ & $\begin{array}{l}\text { All } \\
\text { SEGs } \\
10 y \\
1968-77\end{array}$ & $\begin{array}{l}\text { Farmers } \\
(S E G \quad 0) \\
9 y \\
1979-87\end{array}$ & $\begin{array}{l}\text { All } \\
\text { SEGs } \\
10 y \\
1978-87\end{array}$ \\
\hline $\begin{array}{l}15-24 \\
25-34 \\
35-44 \\
45-54 \\
55-64 \\
65-74 \\
75+ \\
\text { All }\end{array}$ & $\begin{array}{r}- \\
0.5 \\
1.8 \\
4.4 \\
10.5 \\
10.7 \\
1.2 \\
4.7\end{array}$ & $\begin{array}{r}0.9 \\
1.4 \\
3.7 \\
7.1 \\
10 \cdot 2 \\
8.0 \\
2.7 \\
4.5\end{array}$ & $\begin{array}{r}- \\
2 \cdot 0 \\
4 \cdot 4 \\
11 \cdot 3 \\
17 \cdot 0 \\
17 \cdot 1 \\
7 \cdot 8 \\
9 \cdot 4\end{array}$ & $\begin{array}{r}0.9 \\
2.6 \\
4.0 \\
11.1 \\
16.5 \\
17.6 \\
10.9 \\
6.9\end{array}$ & $\begin{array}{l}- \\
1.4 \\
1.8 \\
2.9 \\
4.0 \\
3.0 \\
1.6 \\
2.2\end{array}$ & $\begin{array}{l}0.7 \\
1.0 \\
2.1 \\
3.5 \\
6.0 \\
4.2 \\
1.9 \\
2.6\end{array}$ & $\begin{array}{r}- \\
1.6 \\
5.0 \\
2.8 \\
8.4 \\
13.9 \\
15.2 \\
5.9\end{array}$ & $\begin{array}{r}0.9 \\
1.6 \\
3.0 \\
5.6 \\
11.9 \\
13.9 \\
7.3 \\
5.0\end{array}$ \\
\hline Number & 94 & 456 & 171 & 824 & 32 & 265 & 69 & 607 \\
\hline
\end{tabular}

SEG = Socioeconomic group.

Data for 1968-77 are based on 1971 census; those for 1978-87 are based on 1981 census. 
Table 2 Republic of Ireland deaths from malignant neoplasm of the brain (ICD code 191) 1979-87 by socioeconomic group

\begin{tabular}{|c|c|c|c|c|c|c|c|c|}
\hline \multirow{2}{*}{\multicolumn{2}{|c|}{ Group }} & \multicolumn{2}{|l|}{ Men } & \multicolumn{2}{|l|}{ Women } & \multicolumn{2}{|l|}{ Total } & \multirow{2}{*}{$\begin{array}{l}\text { Total of actual } \\
\text { proportionately } \\
\text { increased by } \\
120 \text { excess in } \\
\text { unknown (325-205) }\end{array}$} \\
\hline & & $\begin{array}{l}\text { Actual } \\
\text { deaths }\end{array}$ & $\begin{array}{l}\text { Expected } \\
\text { deaths }\end{array}$ & $\begin{array}{l}\text { Actual } \\
\text { deaths }\end{array}$ & $\begin{array}{l}\text { Expected } \\
\text { deaths }\end{array}$ & $\begin{array}{l}\text { Actual } \\
\text { deaths }\end{array}$ & $\begin{array}{l}\text { Expected } \\
\text { deaths }\end{array}$ & \\
\hline \multirow{2}{*}{$\begin{array}{l}0 \\
1\end{array}$} & $\begin{array}{l}\text { Farmers, relatives assisting } \\
\text { farmers and farm managers }\end{array}$ & 171 & $186 \cdot 6$ & 69 & $77 \cdot 7$ & 240 & $264 \cdot 4$ & $268 \cdot 4$ \\
\hline & $\begin{array}{l}\text { occupations and fishermen } \\
0+1\end{array}$ & 24195 & ${ }^{39 \cdot 5^{*}} 226 \cdot 1^{*}$ & 372 & ${ }^{12 \cdot 8+} 90 \cdot 5^{*}$ & $27 \quad 267$ & $\begin{array}{l}52 \cdot 3 \dagger \\
316 \cdot 6 \dagger\end{array}$ & $30 \cdot 2 \dagger$ \\
\hline \multirow{4}{*}{$\begin{array}{l}2 \\
3 \\
4 \\
5 \\
6\end{array}$} & Higher professional & 23 & $29 \cdot 7$ & 16 & $19 \cdot 1$ & 39 & $48 \cdot 8$ & 43.6 \\
\hline & Lower professional & 18 & $21 \cdot 4$ & 33 & $32 \cdot 9$ & 51 & $54 \cdot 3$ & $57 \cdot 0$ \\
\hline & Employers and managers & 45 & $49 \cdot 0$ & 17 & $27 \cdot 1^{*}$ & 62 & $76 \cdot 1$ & $69 \cdot 3$ \\
\hline & $\begin{array}{l}\text { Salaried employees } \\
\text { Intermediate non-manual }\end{array}$ & 11 & $17 \cdot 2$ & 6 & $8 \cdot 1$ & 17 & $25 \cdot 3$ & $19 \cdot 0$ \\
\hline & workers & 79 & $64 \cdot 4$ & 69 & $70 \cdot 9$ & 148 & $135 \cdot 3$ & $165 \cdot 5^{*}$ \\
\hline \multirow{6}{*}{$\begin{array}{l}7 \\
8 \\
9 \\
X \\
Y\end{array}$} & Other non-manual workers & 71 & $74 \cdot 5$ & 53 & $55 \cdot 7$ & 124 & $130 \cdot 2$ & $138 \cdot 7$ \\
\hline & Skilled manual workers & 117 & $128 \cdot 0$ & 50 & $60 \cdot 8$ & 167 & $188 \cdot 8$ & $186 \cdot 8$ \\
\hline & Semi-skilled manual workers & 31 & $32 \cdot 2$ & 20 & 29.9 & 51 & $62 \cdot 1$ & $57 \cdot 0$ \\
\hline & Unskilled manual workers & 57 & $68 \cdot 7$ & 30 & $26 \cdot 9$ & 87 & $\begin{array}{r}95 \cdot 6 \\
9\end{array}$ & $97 \cdot 3$ \\
\hline & Unknown & $126 \dagger$ & $61 \cdot 7$ & $199 \dagger$ & $143 \cdot 1$ & $325 \dagger$ & $204 \cdot 8$ & 205 \\
\hline & Total & 773 & $772 \cdot 9$ & 565 & $565 \cdot 0$ & 1338 & $1337 \cdot 9$ & $1337 \cdot 8$ \\
\hline
\end{tabular}

*Significant, $p=0.05 ;$ t significant, $p=0.01$.

the calculated expected number at all Republic of Ireland rates for brain cancer and for each of the various groups of lymphatic and haematopoietic cancers. The slight excess of 17 actual and 10 expected deaths in females aged $65+$ for "monocytic and other leukaemia" represents a diagnosis of "leukaemia" on the death certificate without reference to the type. Other agricultural occupations and fishermen (SEG 1) show significantly fewer deaths in males than expected in all the cancer groups studied, except for lymphoid leukaemia, and in females there are significantly fewer deaths except for lymphoid cancers and lymphoid leukaemia.

When both SEGs 0 and 1 are combined, males have significantly fewer brain cancer deaths (195) than the calculated expected number $\left(226.1\left(\chi^{2}=4.3 p<0.05\right)\right)$ and fewer lymphatic and haematopoietic cancers (712) than expected $\left(783.6\left(\chi^{2}=6.5 \mathrm{p}<0.05\right)\right)$. There are also fewer myeloid leukaemia deaths $(151)$ than expected $\left(187.7\left(\chi^{2}=7.2 \mathrm{p}<0.01\right)\right)$ when both sexes are taken together.

The actual and expected number of deaths, age standardised for males and females, for all socioeconomic groups and for the various lymphatic and haematopietic cancer deaths studied are shown in table 4. Farmers (SEG 0) have the expected number of deaths in all the cancer groups studied and other agricultural occupations and fishermen (SEG 1) have significantly fewer of these cancer deaths except for lymphoid leukaemia. For the other SEGs there is not a great difference between the actual and expected number of cancer deaths, although taking these cancers together, other nonmanual workers (SEG 7) and skilled manual workers (SEG 8) have fewer deaths than expected.

The excess of deaths where the SEG was not known at death (SEG Y), has been divided proportionately in the last column of table 4 . Because relatively few farmers or farmers relatives retire from their farms in Ireland, most of the deaths in SEG Y (occupation unknown) were of people living in Dublin or other towns. Nevertheless, when the relative proportion of SEG deaths are added to the male farmers, there is still not a significant excess of haematopoietic cancer deaths in each subgroup, although there is if all these cancer groups are included together. In multiple myeloma, after adding the proportion of unknown deaths, the calculated number of deaths in male farmers is 171 and the expected value is $146.4\left(\chi^{2}=4 \cdot 1\right.$ $\mathrm{p}<0.05)$. This difference is probably an

Table 3 Republic of Ireland malignant neoplasm of the brain and of the haematopoietic system: actual and expected number of deaths in 1979-87 by age group

\begin{tabular}{|c|c|c|c|c|c|c|c|c|c|}
\hline \multirow{3}{*}{$\begin{array}{l}I C D \\
\text { code }\end{array}$} & & \multicolumn{4}{|c|}{ Men } & \multicolumn{4}{|l|}{ Women } \\
\hline & & \multicolumn{2}{|c|}{$15-64 y$} & \multicolumn{2}{|l|}{$65+y$} & \multicolumn{2}{|l|}{$15-64 y$} & \multicolumn{2}{|l|}{$65+y$} \\
\hline & & Actual & Expected & Actual & Expected & Actual & Expected & Actual & Expected \\
\hline \multicolumn{10}{|c|}{ SEG 'O' Farmers, relatives assisting farmers, and farm managers } \\
\hline 191 & Malignant neoplasm of brain & 104 & $108 \cdot 4$ & 67 & $78 \cdot 2$ & 36 & $49 \cdot 2$ & 33 & 28.5 \\
\hline $200-202$ & Lymphoid cancers, Hodgkin's & 92 & 86.9 & 122 & 130.8 & 27 & 35.8 & 45 & 40.5 \\
\hline 203 & Multiple myeloma & 40 & 38.7 & 112 & $107 \cdot 7$ & 16 & 19.9 & 46 & 37.9 \\
\hline 204 & Lymphoid leukaemia & 24 & 23.9 & 89 & 91.0 & 8 & $9 \cdot 0$ & 27 & $19 \cdot 1$ \\
\hline 205 & Myeloid leukaemia & 29 & $32 \cdot 2$ & 78 & 82.5 & 11 & 17.9 & 24 & 22.5 \\
\hline 206-208 & Monocytic and other leukaemias & 8 & 7.6 & 35 & 38.8 & 5 & 5.7 & 17 & $10 \cdot 1$ \\
\hline $202-208$ & Lymphatic and haematopoietic cancers 1 & 193 & $189 \cdot 3$ & 436 & 450.8 & 67 & $88 \cdot 3$ & 159 & $130 \cdot 1$ \\
\hline \multicolumn{10}{|c|}{ SEG 0 and SEG 1 combined } \\
\hline 191 & Malignant neoplasm of brain & 122 & 129.6 & 73 & $96 \cdot 5^{*}$ & $39^{*}$ & $57 \cdot 4$ & 33 & 33.1 \\
\hline $200-202$ & Lymphoid cancers, Hodgkin's & 108 & $104 \cdot 2$ & 136 & $161 \cdot 5^{*}$ & 33 & $42 \cdot 0$ & 51 & 46.9 \\
\hline & Multiple myeloma & 44 & 45.8 & 126 & $132 \cdot 1$ & 16 & $23 \cdot 1$ & 56 & 43.9 \\
\hline 204 & Lymphoid leukaemia & 32 & 28.6 & 106 & $112 \cdot 4$ & 9 & $10 \cdot 6$ & 30 & $22 \cdot 1$ \\
\hline 205 & $\begin{array}{l}\text { Myeloid leukaemia } \\
\text { a }\end{array}$ & 30 & 38.9 & 84 & 101.9 & 12 & $20 \cdot 9$ & 25 & $26 \cdot 0$ \\
\hline 206-208 & Monocytic and other leukaemias & 8 & $9 \cdot 2$ & 38 & 48.0 & 5 & $6 \cdot 7$ & 19 & $11 \cdot 7$ \\
\hline $202-208$ & Lymphatic and haematopoietic cancers 2 & & & & & & & & \\
\hline
\end{tabular}

* Significant $\mathrm{p}<0.05$. 
Table 4 Republic of Ireland actual and expected deaths from haematopoietic cancers (ICD 200-208), 1979-87

\begin{tabular}{|c|c|c|c|c|c|c|c|c|c|c|c|c|c|c|}
\hline \multirow[b]{2}{*}{$S E G$} & \multicolumn{2}{|c|}{$\begin{array}{l}\text { Code 200-202 } \\
\text { lymphoid, } \\
\text { Hodgkin's }\end{array}$} & \multicolumn{2}{|c|}{$\begin{array}{l}\text { Code } 203 \\
\text { multiple } \\
\text { myeloma }\end{array}$} & \multicolumn{2}{|c|}{$\begin{array}{l}\text { Code } 204 \\
\text { lymphoid } \\
\text { leukaemia }\end{array}$} & \multicolumn{2}{|c|}{$\begin{array}{l}\text { Code } 205 \\
\text { myeloid } \\
\text { leukaemia }\end{array}$} & \multicolumn{3}{|c|}{$\begin{array}{l}\text { Codes 206-208 } \\
\text { monocytic } \\
\text { Eo other } \\
\text { leukaemias }\end{array}$} & \multicolumn{2}{|c|}{$\begin{array}{l}\text { Total, codes } \\
200-208\end{array}$} & \multirow{2}{*}{$\begin{array}{l}\text { Total codes } 200-208 \\
\text { calculated actual } \\
\text { deaths, adding excess } \\
\text { in SEG Y } \\
\text { proprtionately } \\
\text { to other SEGs }\end{array}$} \\
\hline & Act & $\operatorname{Exp}$ & Act & $\operatorname{Exp}$ & Act & $\operatorname{Exp}$ & Act & $\operatorname{Exp}$ & & Act & $\operatorname{Exp}$ & $A c t$ & $\operatorname{Exp}$ & \\
\hline \multicolumn{15}{|l|}{ Men: } \\
\hline $\begin{array}{ll}0 & (242 \cdot 4)\end{array}$ & ) 214 & 217.7 & (171) 152 & $146 \cdot 4$ & $(128 \cdot 7) 113$ & $1.14 \cdot 9$ & $(131 \cdot 6) 107$ & $114 \cdot 7$ & $(49 \cdot 8)$ & ) 43 & $46 \cdot 4$ & 629 & $640 \cdot 1$ & $723.8 \dagger$ \\
\hline $1 \quad(34-0)$ & 1) 30 & 48.0 & $(20 \cdot 2) \quad 18$ & 32.5 & $(28.5) \quad 25$ & $26 \cdot 1$ & (8.6) 7 & $26 \cdot 1$ & (3.5) & ) 3 & $10 \cdot 8$ & 83 & 143.5 & $95.5 \dagger$ \\
\hline 2 & 25 & 29.6 & 11 & 15.2 & 11 & 11.8 & 14 & $14 \cdot 2$ & & 7 & 4.9 & 68 & $75 \cdot 7$ & $78 \cdot 2$ \\
\hline 3 & 21 & $21 \cdot 3$ & 10 & $10 \cdot 2$ & 9 & $8 \cdot 3$ & 12 & 10.4 & & 1 & 3.4 & 53 & 53.6 & $61 \cdot 0$ \\
\hline 4 & 38 & 47.5 & 21 & $23 \cdot 5$ & 16 & 17.8 & 16 & 21.8 & & 2 & 6.9 & 93 & 117.5 & $107 \cdot 0$ \\
\hline 5 & 7 & $17 \cdot 4$ & 10 & $9 \cdot 0$ & 4 & $7 \cdot 1$ & 6 & $8 \cdot 3$ & & 3 & $2 \cdot 8$ & 30 & $44 \cdot 6$ & 34.5 \\
\hline 6 & 58 & 69.9 & 39 & 37.4 & 26 & $31 \cdot 6$ & 31 & 35.7 & & 12 & 12.9 & 166 & 187.5 & 191.0 \\
\hline 7 & 63 & 74.0 & 18 & 38.3 & 22 & $29 \cdot 4$ & 20 & 35.0 & & 9 & $11 \cdot 2$ & 132 & $187.9+$ & $151.9^{*}$ \\
\hline 8 & 104 & 128.9 & 42 & $62 \cdot 0$ & 37 & $50 \cdot 7$ & 43 & $62 \cdot 3$ & & 17 & $20 \cdot 3$ & 243 & $324 \cdot 2 \dagger$ & $279 \cdot 6 \dagger$ \\
\hline 9 & 30 & $31 \cdot 4$ & 16 & 15.0 & 9 & $12 \cdot 0$ & 16 & $14 \cdot 7$ & & 5 & $4 \cdot 7$ & 76 & $77 \cdot 8$ & $87 \cdot 4$ \\
\hline $\mathrm{x}$ & 83 & 76.2 & 50 & 45.9 & 32 & 36.6 & 39 & 39.0 & & 18 & $14 \cdot 6$ & 222 & $212 \cdot 3$ & $255.4 \dagger$ \\
\hline $\mathbf{Y}$ & 163 & 73.8 & 97 & 48.7 & 82 & $39 \cdot 6$ & 111 & 39.5 & & 35 & $16 \cdot 0$ & 488 & 217.6 & $217 \cdot 6$ \\
\hline Total & 836 & 835.7 & 484 & 484.1 & 386 & 385.9 & 422 & $421 \cdot 7$ & & 155 & 154.9 & 2283 & 2282.3 & $2282 \cdot 9$ \\
\hline \multicolumn{15}{|l|}{ Women: } \\
\hline 0 & 72 & $76 \cdot 3$ & 62 & 57.8 & 35 & $28 \cdot 1$ & 35 & $40 \cdot 4$ & & 22 & 15.8 & 226 & 218.4 & $240 \cdot 2$ \\
\hline 1 & 12 & 12.6 & 10 & $9 \cdot 2$ & 4 & $4 \cdot 6$ & 2 & $6 \cdot 5$ & & 2 & $2 \cdot 6$ & 30 & 35.5 & 31.9 \\
\hline 2 & 18 & $18 \cdot 4$ & 13 & $12 \cdot 7$ & 9 & $6 \cdot 4$ & 8 & $10 \cdot 2$ & & 1 & 3.7 & 49 & $51 \cdot 4$ & $52 \cdot 1$ \\
\hline 3 & 31 & $32 \cdot 1$ & 23 & $20 \cdot 4$ & 12 & 12.0 & 13 & 17.8 & & 9 & 6.6 & 88 & 88.9 & 93.5 \\
\hline 4 & 31 & $23 \cdot 3$ & 19 & 14.3 & 9 & 7.4 & 10 & 12.7 & & 3 & $4 \cdot 3$ & 72 & $62 \cdot 0$ & 76.5 \\
\hline 5 & 9 & 6.9 & 9 & $4 \cdot 2$ & 5 & $2 \cdot 2$ & 8 & 3.8 & & 1 & $1 \cdot 2$ & 32 & 18.3 & $34.0+$ \\
\hline 6 & 58 & 66.8 & 30 & 41.8 & 22 & 25.9 & 32 & 36.5 & & 16 & $14 \cdot 3$ & 158 & 185.3 & 167.9 \\
\hline 7 & 44 & 51.9 & 36 & 34.5 & 17 & 18.4 & 22 & $28 \cdot 1$ & & 10 & $10 \cdot 4$ & 129 & 143.3 & $137 \cdot 1$ \\
\hline 8 & 41 & $52 \cdot 1$ & 21 & 31.0 & 6 & 16.2 & 19 & 28.4 & & 7 & 9.5 & 94 & 137.2 & 99.9 \\
\hline 9 & 19 & 26.5 & 17 & 16.6 & 4 & 9.5 & 12 & $14 \cdot 3$ & & - & $5 \cdot 3$ & 52 & $72 \cdot 2$ & $55 \cdot 3^{*}$ \\
\hline $\mathrm{x}$ & 27 & 25.0 & 28 & 17.3 & 8 & 8.5 & 18 & $13 \cdot 2$ & & 6 & 4.9 & 87 & 68.9 & $92 \cdot 4$ \\
\hline $\mathbf{Y}$ & 225 & $195 \cdot 2$ & 161 & $169 \cdot 3$ & 103 & 95.0 & 143 & $110 \cdot 2$ & & 52 & $50 \cdot 6$ & 684 & $620 \cdot 3$ & $620 \cdot 3$ \\
\hline Total & 587 & $587 \cdot 1$ & 429 & $429 \cdot 1$ & 234 & $234 \cdot 2$ & 322 & $322 \cdot 1$ & & 129 & 129.2 & 1701 & $1701 \cdot 7$ & $1701 \cdot 1$ \\
\hline
\end{tabular}

artefact because few farmers' occupation is unknown. When SEGs 0 and 1 are taken together, there is no significant increase in multiple myeloma deaths over the expected number, even when the relative proportion of unknown deaths is added (table 4).

\section{Discussion}

While there are some differences in the way occupation is recorded on death certificates and at the census, general conclusions can be made. In the Republic of Ireland deaths from primary brain cancers are more common in men than in women and there has been a doubling of deaths reported as due to brain cancer between 196877 and 1978-87. The increase is most marked over the age of 65 , suggesting that improved diagnosis may be at least a partial explanation for the increase. The possiblity of a true increase in brain cancers in the population as a whole requires further investigation.

Deaths from Hodgkin's disease, lymphatic cancers, and from multiple myeloma are also more commonly reported in men than in women. These cancers increased in the two time periods studied, but the increase has not been as great as that which has occurred with brain cancer.

The increase in reported deaths from myeloid and lymphatic leukaemia is largely explained by more accurate reporting, fewer deaths are now reported as "leukaemia" without a description of type.

Farmers, farm managers, and relatives assisting farmers do not have any significantly increased risk of dying from brain, lymphatic, or haematopoietic cancers compared with the general population when each cancer group is taken separately. Other agricultural occupations and fishermen (who are mostly farm labourers) have fewer deaths from brain and haematopoietic cancer than would be expected at national rates. There is no evidence, therefore, that farming in Ireland increased the risk of developing brain cancer or lymphatic cancer, including Hodgkin's disease, multiple myeloma, or leukaemia, in comparison with the general population. The cluster of deaths from brain cancers and haematopoietic cancers that has been noted among the research and technical staff of the former Agricultural Institute of Ireland, and in the Pasteur and Orsay Institutes in Paris, is not reflected by any increase in these cancer groups among farmers in general in Ireland. It is still possible that there may be a subgroup of farmers that have a higher than normal risk of developing these cancers, but whatever the cause of the clusters of deaths from these cancers among research workers, there is no greater risk of developing these cancers in the general population of farmers in Ireland than occurs in the population as a whole.

Further studies are being undertaken at an international level to ascertain if research workers are subject to any undue risks of cancer associated with their work and, if there is such a risk, to ascertain what it is so that it can be avoided. As suggested by Rutty et $a l^{4}$ and also by an editorial in the Lancet $^{9}{ }^{9}$ there are good reasons why a register of the causes of death of laboratory workers should be compiled in a number of countries. A retrospective cohort study of personnel employed over the past 20 years in biomedical or agronomic research institutes in Europe has now been set up under the aegis of the International Agency for Research in Cancer (IARC), Lyon. ${ }^{10}$ 
I thank Dr Pierce Ryan, Director of TEAGASC, the Agriculture $\&$ Food Development Authority, and formerly Director of An Foras Taluntais, the Agricultural Institute, for inviting me in 1985 to undertake a pilot study on the causes of death of the research and technical workers at the Institute. Dr Alan O'Grady, Medical Advisor to the Institute and Mr William Barry, Head of Personnel, provided the background information that made the study possible. I would also like to thank $\mathrm{Dr}$ that made the study possible. I would also like to thank Dr Calum Muir and Dr Annie J Sasco of the International Agency
for Research on Cancer, Lyon, and also Mr R Haigh, Head of the for Research on Cancer, Lyon, and also Mr R Haigh, Head of the Industrial Medicine and Hygiene Unit of the Commission of the European Communities, who advised me about further studies
on the causes of death among agricultural workers. Mr Tom Linehan, Director of the Central Statistics Office of Ireland, and Ms Evelyn Byrne provided the detailed information on which the study was based. The study was undertaken on behalf of the Commission of the European Communities.

1 Dean G. Investigation of the causes of death among the research and technical staff employed by the Agricultural Institute of and technical staff employed by the Agricultural Institute of
Ireland. Report to the International Agency for Research on
Cancer (IARC), Lyon, and the Health and Safety Division of the Economic European Commission. January 1988. Cardier S. Risk of cancer among laboratory workers. Lancet 1991;338:1080-1.

3 Pleven C, et al. Survenue de glioblastomes chéz des personnels de laboratoires de recherche travaillant sur des produits nitroses. F Toxicologie Médicale 1984;3:249-57.

4 Rutty GN, Honavar M, Doshi B. Malignant glioma in laboratory workers. f Clin Pathol 1991;44:868-69.

5 laboratory workers. JW Aw T-C. Mortality study of British pathologists. Am $\mathcal{f}$ Ind Med 1991;20:83-9.

pathologists. Am 7 Ind Med 1991;20:83-9.
Pearce NE, Sheppard RA, Howard JK, Fraser J, Lilley BM.

Leukaemia among New Zealand Agricultural workers; Leukaemia among New Zealand Agricultural workers; 24(3):402-07.

7 Belli S, Comba P, de Santis M, Grignoli M, Sasco AJ Mortality study of workers employed by the Italia National Institute of Health, 1960-1989. Scand $\mathcal{F}$ Work Environ Health 1992;18:64-7.

8 Carpenter L. Cancer in laboratory workers. Lancet 1990 335:1097.

9 Anonymous. "Is Pathology dangerous to health?" (Editorial) Lancet 1992;339:277-8.

10 Sasco AJ. Cancer risk in laboratory workers. Lancet 1992;339:684.

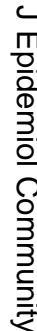

(

